\title{
Effect of Discharge of Partially Treated Refinery Effluent on the Okrika River
}

\begin{abstract}
Keywords: Physiochemical; Effluent; Water quality; Treatment; Permissible limit

Abstract

This study was carried out to determine the effect of the discharge of partially treated refinery effluent on the Okrika River. Standard methods were used to determine the physiochemical parameters of refinery effluent. The laboratory analysis results showed that $\mathrm{pH}$ was 5.6 6.06; temperature was 25.6-26.70-, BOD was 3.36-3.76; COD was 5.165.58 and TDS was $44.7-461 \mathrm{mg} / \mathrm{L}$; The sample results which exceeded DPR standard including odor (objectionable); Turbidity (17-24TU): DO (1.27-3.17 mg/L), Conductivity (68.4-680) and THC (444.2-927.4) as against DPR standard permissible limit of odor (unobjectionable): Turbidity (15TU); DO (4.0-5.0 mg/L) conductivity (N/A) and THC (10): signifying that the River is polluted. This must have lead to observable scanty presence of aquatic life in the River; enhance, rendered the river water not conducive for domestic use. The researchers' recommended strict adherent to DPR standard permissible limit for effluent discharge couple with routine enforcement inspection to ensure compliance.
\end{abstract}

\section{Introduction}

Water quality is major problem in the $21^{\text {st }}$ century. Therefore, effective treatment of various effluents before discharging into receiving water body is the only requirement that meets acceptable standard [1]. Industrialization is considered the corner stone of development strategies due to its significant contribution to economic growth and human welfare. It has become a yard stick for placing countries in the League of Nations and index of its political stature $[2,3]$. Industrialization, like other human activities that impact on the environment, often results in pollution and degradation [4]. Such environmental degradation carries inevitable costs implications $[5,6]$. World-wide water bodies are the primary means for disposal of waste, especially the effluents, from industries that are near them. These refinery effluents have a great deal of influence on the receiving/surrounding water body; as it alters the physical, chemical and biological nature of the water body [7].

Industries turn out waste which are peculiar in terms of type, frequency and volume depending on the type of industry and population that uses the product [8]. Industrial waste is the most common source of water pollution which stimulates bloom of algae, heavy metals, inorganic and organic toxic substances [9-11]. The water bodies suffer significant deterioration of natural quality as industrial discharges are released into it. The assimilatory capacity of the river helps to regulate the level of pollution which results from such untreated discharges [12]. The extent of discharge of domestic and industrial waste is such that rivers receiving untreated effluent cannot give dilution necessary for their survival as good quality water sources.

Industries are the major sources of pollution to the environment as various pollutants are released into the surrounding environment
Journal of

Environmental Studies

\author{
John NU* and Chimka El \\ Department of Civil and Environmental Engineering, University of \\ Port Harcourt, Nigeria \\ *Address for Correspondence \\ John NU, Department of Civil and Environmental Engineering, \\ University of Port Harcourt, Nigeria; E-Mail: johnugbebor@yahoo.com; \\ john.ugbebor@uniport.edu.ng \\ Submission: 26 October, 2017 \\ Accepted: 27 November, 2017 \\ Published: 30 November, 2017 \\ Copyright: (๑) 2017 John NU, et al. This is an open access article \\ distributed under the Creative Commons Attribution License, which \\ permits unrestricted use, distribution, and reproduction in any medium, \\ provided the original work is properly cited.
}

directly or indirectly, making the water unsuitable for drinking, domestic use, recreational and agricultural purposes [5]. Water pollution especially by oil is a very serious problem in the entire world because it causes direct lethal toxicity, disruption of physiological activities and changes in biological habitat [13]. It threatens the health and wellbeing of humans, plants and animals. As the world become more industrial and smaller due to globalization through communications and trade, accidental and purposive hazardous dumping has contributed largely to the problem of water pollution. Water pollution therefore is detrimental to the public health of living organisms, humans and animals $[14,15]$.

The various pollutants released into the Okrika River affect the littoral zone, the shallow waters along the shore where rooted vegetation and algae grow [15].

\section{Area of study}

The sampling stations were established at the Okrika River, at Okrika Local Government Area, in Rivers State. The main source of the river is the Bonny River. People who live in communities around the river are mostly fisher men and farmers (Figure 1).

The Water from the river is also used for irrigation by farmers who farm along the bank of the river. The river serves as a means of livelihood for people who fish and those who depend on the river for growing their crops especially in dry seasons. The Okrika River is confined in salt water swamp zone and Port Harcourt refinery discharges their effluent into the river.

\section{Methodology}

Materials for water sampling

The materials for water sampling include

i. $\quad 1 \mathrm{~L}$ plastic sample containers (7 of them)

ii. Cooler to preserve the samples

iii. Ice blocks

iv. Masking tape

v. Global Positioning System (GPS) 


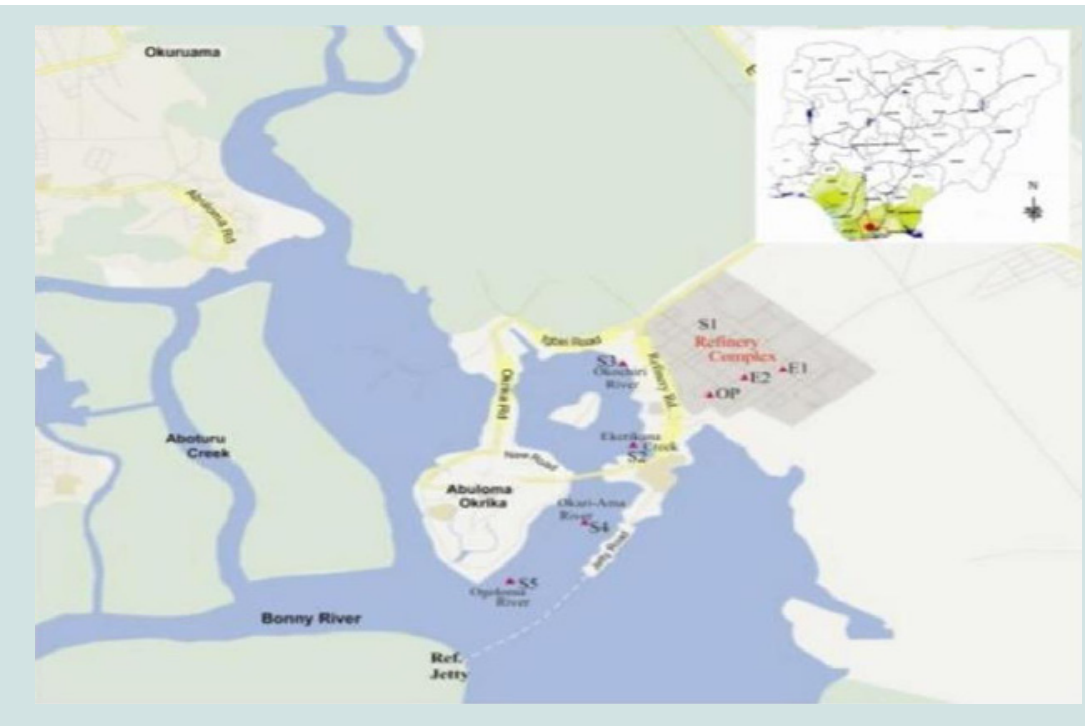

Figure 1: Map showing study area.

\section{Water sample collection}

Seven stations were established for the sampling activities. The first station where the first sample was collected is a channel for domestic water discharge. Based on the field conditions as observed, the refinery effluent was discharged at the beginning of the river through a canal. This made it impracticable to sample for control upstream. Hence, having carefully considered the objectives of the study, the control sample was collected at station 1 before the water mixed up with the canal discharging the refinery effluents. Station 2 was the point of direct discharge from the refinery. At this location, the sample labelled effluent was collected. From the beginning of the river, five others stations were sampled along the length of the river at $50 \mathrm{~m}$ apart. These were respectively labelled point 1 through point 5 . In situ analyses were performed using Extech water meters and the collected samples preserved in an ice chest for further analysis in the laboratory. BOD samples were collected in standard BOD bottles.

Distances along the river were measured with an odometer. The stations were also geo-located with GPS. All field observations were recorded in the field book.

\section{Laboratory analysis}

The physiochemical/ Electrochemical parameters that were analyzed include, Biochemical oxygen Demand (BOD), Chemical Oxygen Demand (COD), conductivity, Dissolved Oxygen (DO), Hydrogen ion concentration ( $\mathrm{pH}$ ), Salinity, Temperature, Turbidity, Total dissolved solids, Total suspended solids, and Total Hydrocarbon content. These parameters were determined using USEPA standard method.

\section{Results}

Table 1: Okrika River: water sample.

\begin{tabular}{|c|c|c|c|c|c|c|c|c|}
\hline Parameter (Mints) & Contro L & Effluent & St 1 & St 2 & St 3 & St 4 & St 5 & DPR \\
\hline $\mathrm{pH}$ & 5.97 & 6.87 & 6.38 & 6.06 & 5.78 & 5.6 & 5.68 & $6.5-8.5$ \\
\hline Temp. oC & 25.7 & 25.6 & 26.7 & 26.2 & 26.5 & 26.3 & 26.2 & 30 \\
\hline Salinity(mg/l) & 0.03 & 0.22 & 0.21 & 0.25 & 0.24 & 0.33 & 0.27 & N/A \\
\hline Colour & 40 & 246 & 199 & 197 & 166 & 244 & 190 & N/A \\
\hline Conductivity $(\mu \mathrm{S} / \mathrm{cm})$ & 68.4 & 445 & 436 & 507 & 500 & 680 & 543 & N/A \\
\hline Turbidity.(NTU) & 9 & 24 & 17 & 18 & 22 & 23 & 22 & 15 \\
\hline Odour & Unobjectionable & Objectionable & Objectionable & Objectionable & Objectionable & Objectionable & Objectionable & Unobjectionable \\
\hline $\mathrm{TSS}(\mathrm{mg} / \mathrm{l})$ & 10 & 5 & 12 & 11 & 10 & 15 & 12 & 30 \\
\hline $\mathrm{DO}(\mathrm{mg} / \mathrm{l})$ & 3.17 & 1.69 & 1.34 & 1.5 & 1.55 & 1.63 & 1.27 & $4.0-5.0$ \\
\hline BOD5(mg/l) & 3.76 & 4.5 & 3.36 & 3.83 & 3.48 & 3.52 & 3.7 & 10 \\
\hline $\mathrm{COD}(\mathrm{mg} / \mathrm{l})$ & 5.58 & 5.2 & 5.43 & 5.65 & 5.16 & 5.32 & 5.52 & 40 \\
\hline TDS(mg/l) & 44.7 & 301 & 294 & 342 & 338 & 461 & 369 & $<2000$ \\
\hline $\mathrm{THC}(\mathrm{mg} / \mathrm{l})$ & 3.6 & 927.4 & 656 & 444.2 & 469.3 & 510 & 492.2 & 10 \\
\hline
\end{tabular}




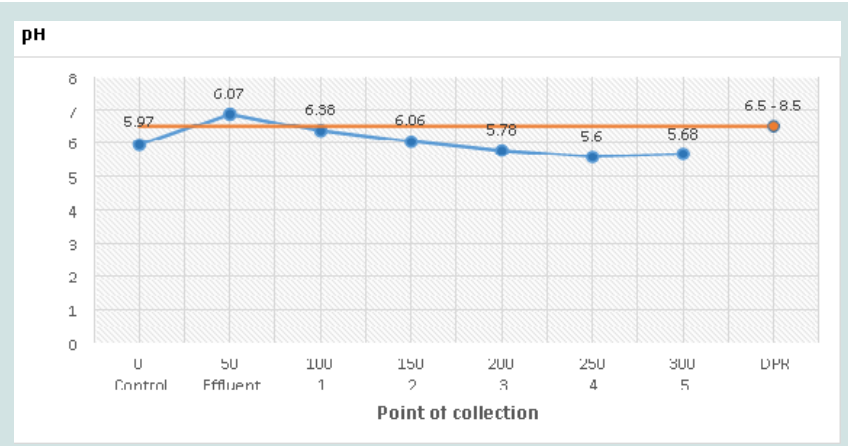

Figure 2: PH values along the study river s at various station.

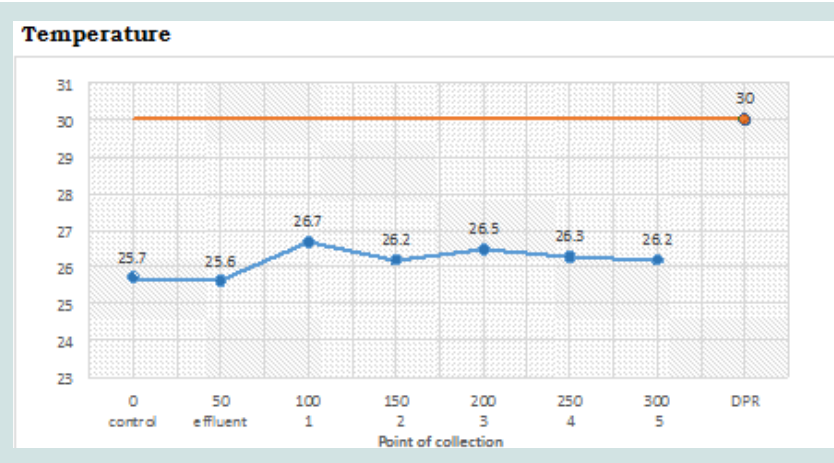

Figure 3: Temperature values along the river at sample stations.

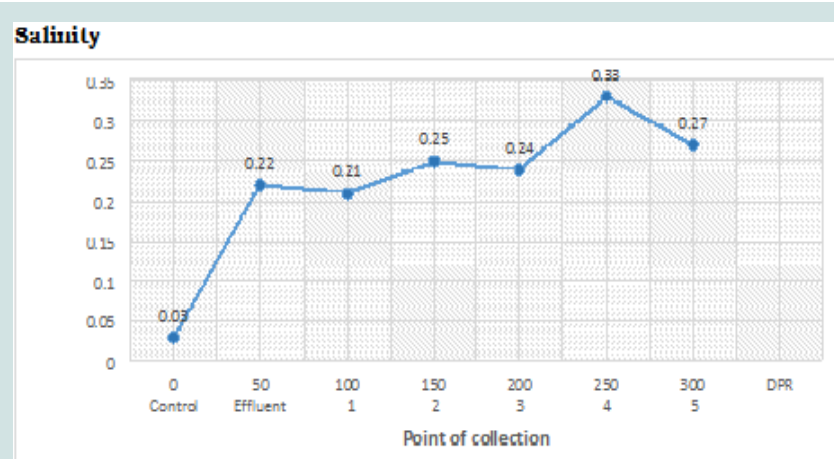

Figure 4: Colour values along the Study Rivers at sample stations.

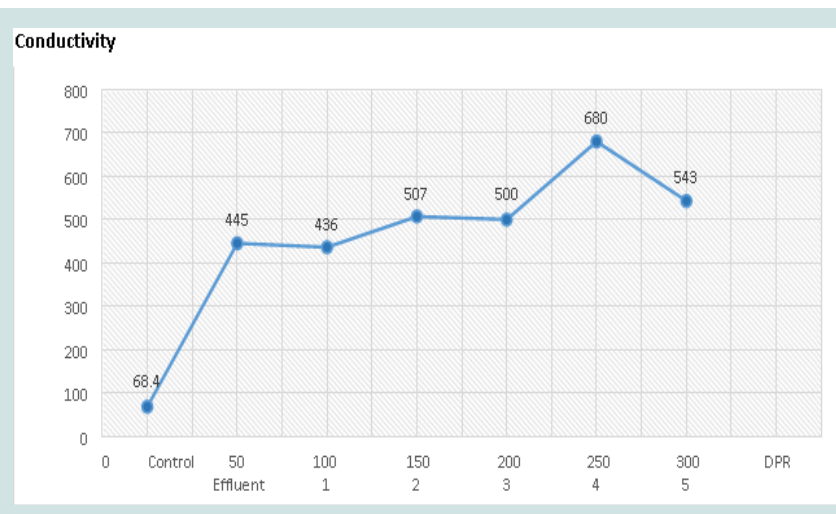

Figure 5: Conductivity values along the Study Rivers at sample stations.

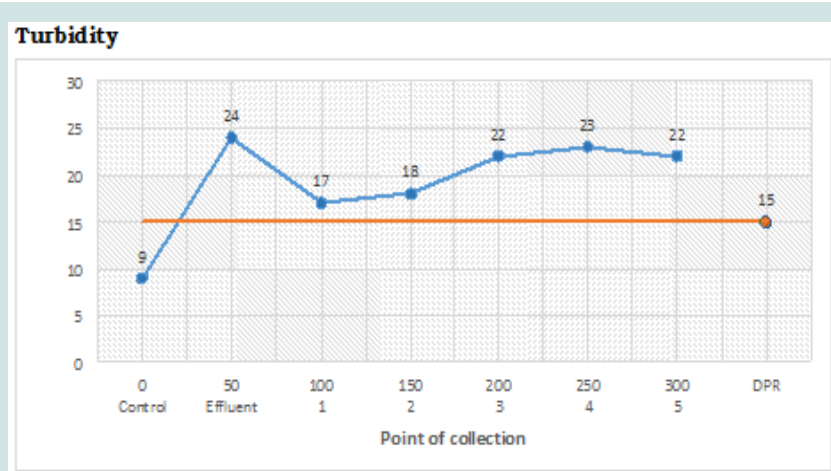

Figure 6: Turbidity values along the study Rivers at various stations.

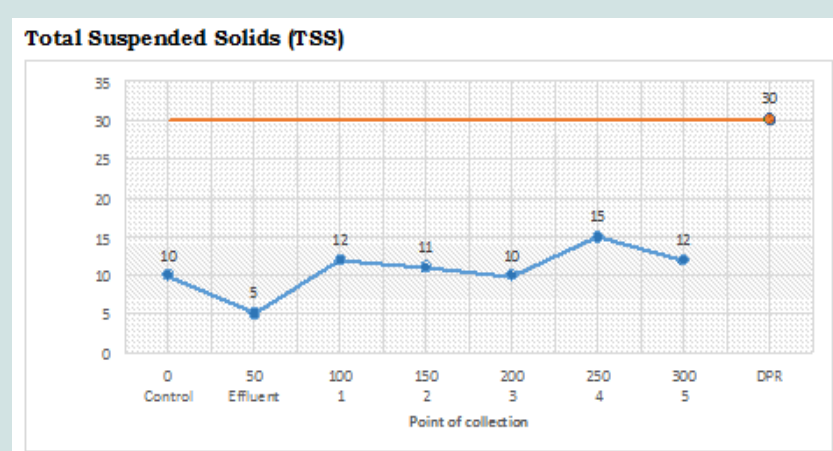

Figure 7: Total Suspended Solids values along the study Rivers sampled stations.

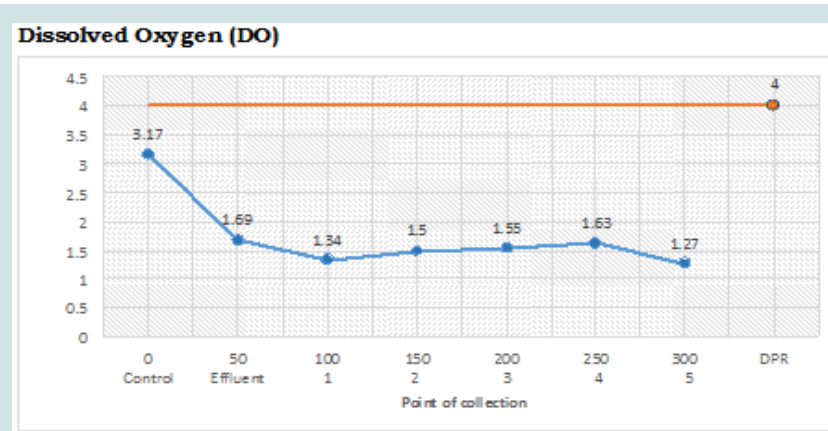

Figure 8: Dissolved Oxygen (DO) values along the Study Rivers.

Biochemical Oxygen Demand (BOD)

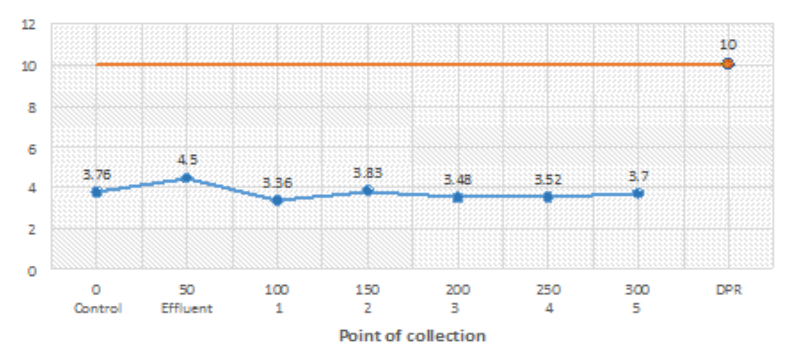

Figure 9: Biochemical Oxygen Demand values along the Rivers Stations. 


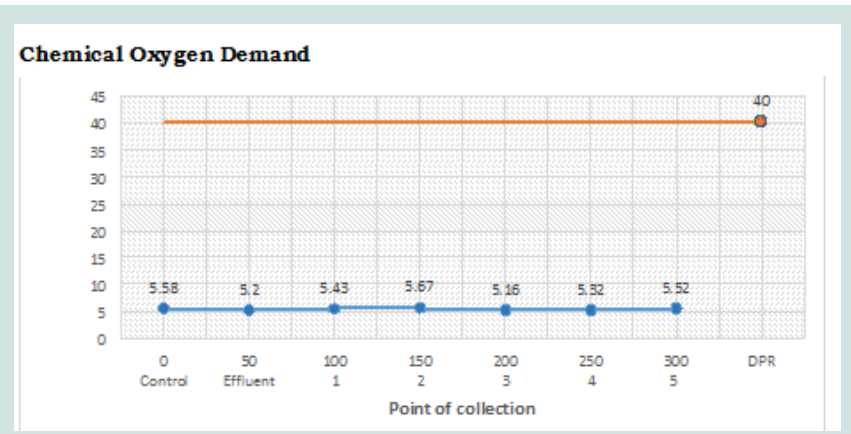

Figure 10: Chemical Oxygen Demand (COD) values at various stations.

Total Dissolved Solids (TDS)

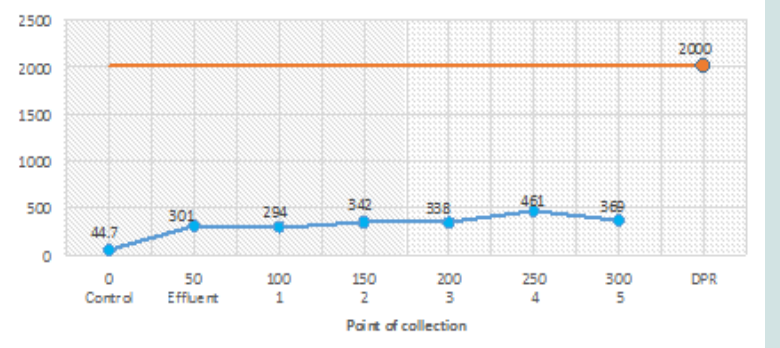

Figure 11: Total Dissolved Solids values at various stations.

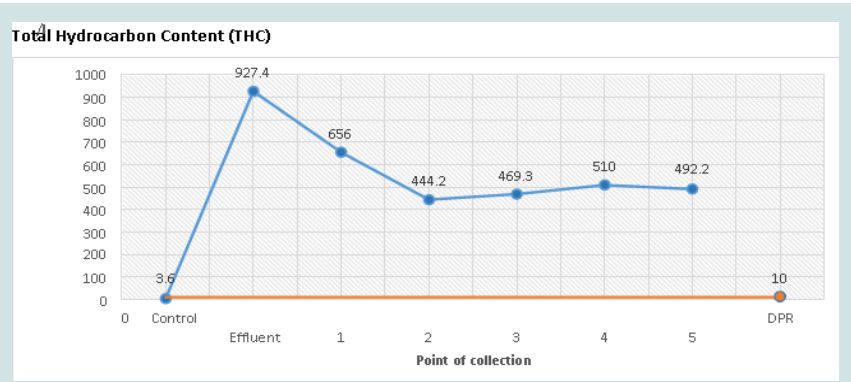

Figure 12: Total Hydrocarbon content (THC) values at various stations.

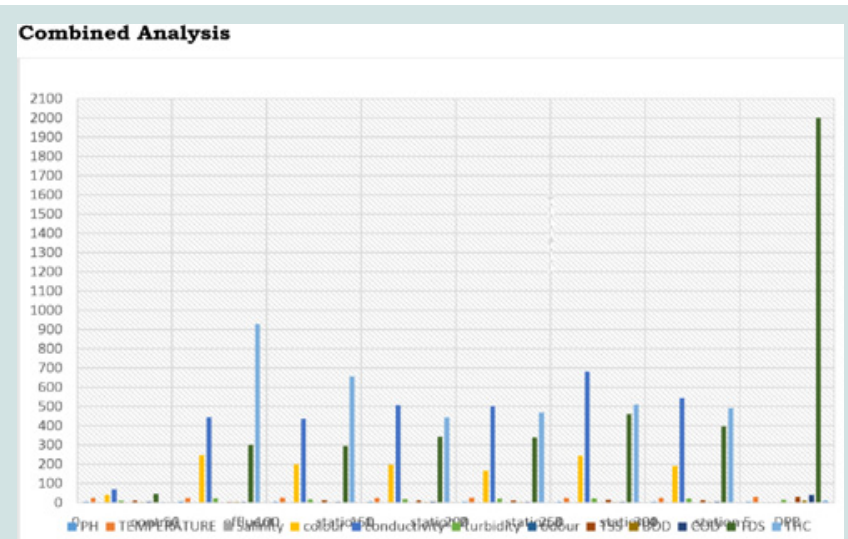

Figure 13: Field parameters in comparison with DPR limit. PH, Temperature Control, Effluent Sanity, Station Colour, Station Conductivity, Station Turbidity, Station Odour, Station TSS, BOD, Station COD, TDS, THC.

\section{Discussion}

The Table 3.1 showed the physiochemical characteristics of the measured samples of Okrika river. The results of these parameters were discussed as follows:

Figure 2 indicated low $\mathrm{pH}$ values in all the seven measured stations with values of $5.97,6.87,6.38,6.06,5.78,5.6$ and 5.68 , at the control stations, effluent station and stations one to five respectively. The standard DPR limit for $\mathrm{pH}$ is 6.5-8.5. The low $\mathrm{pH}$ at station 1 to 5 was as a result of discharges along the river stretch. This is below standard DPR and WHO recommended limit for $\mathrm{pH}$ ranged between 6.5-8.5. The resultant effect of low $\mathrm{pH}$ below DPR limit is that there may be an adverse effect on the biological and biochemical reactions thereby causing health disorder in aquatic lives in the river.

Figure 3 indicated that the temperature values at control station, effluent station and stations one to five were below DPR limits. The temperature range at the various measured stations had direct adverse effect on the biological activity and growth of aquatic organisms, e.g. fish, insects, zooplankton, phytoplankton etc. This had no threat to the homeostatic balance of the river $[14,16]$.

Figure 4 indicated the salinity values in all the seven measured stations with values of $0.03,0.22,0.21,0.25,0.24,0.33$ and 0.27 , at the control stations, effluent station and stations one to five respectively. Since the DPR specification for acceptable salinity was not available, actual inferences of whether the salinity was too high or low cannot be drawn. For the purpose of documentation, some of the effects of high water salinity include reduced crop yield and excess salinity may cause osmotic imbalance in the environment leading to plasmolysis.

Figure 4 indicated the colour values at various stations with values ranging from 40, 246, 199, 197, 244 and 190. The DPR recommended limit for colour was not available and therefore inferences cannot be drawn and the real life implication of these cannot be ascertained.

Figure 5 indicated that the conductivity measured was high with values of 68.4, 445,436,507,500,680 and 543 and not good for living organisms. The DPR specification for acceptable conductivity is not available, though high conductivity is known be harmful to living organisms because of the alteration in osmotic pressure.

Figure 6 indicated a high value of turbidity in six of all the seven measured stations with values of $24,17,18,22,23$ and 22 , which exceeds the permissible limit for DPR and WHO standard of 15NTU and 5NTU (WHO, 2004) respectively. The high turbidity in the river was caused by colloidal suspension from untreated/ partially treated industrial effluent. The effect of high turbidity was that it makes the water from the river less consumable, and polluted because of high microbial contamination and more costly to treat.

Figure 7 indicated low Total Suspended Solids (TSS) values in all the seven measured stations with values of 10,5,12,11,10,15, and 12 , at the control stations, effluent station and stations one to five respectively. The standard DPR limit for TSS is 30NTU

Figure 8 indicated the Dissolved Oxygen (DO) values of 3.17, $1.69,1.34,1.5,1.55,1.63$ and 1.27 for the seven measured stations. All fall below the recommended limit given by DPR limit of 4.0-5 mg/l. It may be as a result of presence of oxygen demanding materials and 
fertilizer run-offs from the nearby farmland. The presences of low DO suggest pollution which may cause death of aquatic lives.

Figure 9 indicated that the BOD values of $3.76,4.5,3.36,3.83$, $3.48,3.52$ and 3.7 at control station, effluent station and stations one to five are below the DPR limit of $10 \mathrm{mg} / \mathrm{l}$. A low BOD was an indication of the presence of low number of microorganisms' mainly aerobic bacteria.

Figure 10 indicated that the COD values in the seven measured stations was also below the DPR upper limit of $40 \mathrm{mg} / \mathrm{l}$. COD is not a desirable parameter since high level of it in water leads to a low DO which results in death to aquatic lives.

Figure 11 indicated Total Dissolved Solids (TDS) values in all the seven measured stations with values of 44.7, 301, 294, 342, 338, 461 and 369 , at the control station, effluent station and stations one to five respectively. The standard DPR limit for TDS is $(<2000)$. The high TDS have laxative effect upon people, whose bodies are not adjusted to them, causes foaming and colour in boilers.

Figure 12 indicated high THC values in all the measured stations with values of 3.6, 927.4, 656, 444.2, 469.3, 510 and 492.2 which are above the DPR permissible limit of $10 \mathrm{mg} / \mathrm{l}$. The effect of high THC is cancer and pollution of the river making it unfit for use.

\section{Odour}

The measured odour values presented in Table 1 indicated that the samples had odour (objectionable) which was not acceptable. This was caused by the presence of strong smelling compounds both organic (algal by- products, decomposing organic matter) and inorganic (ammonia, sulphide). Effects of odour on human and aquatic lives were difficulty in breathing, nose irritation, high level of annoyance and depression.

The combined plot in Figure 13 showed the existing relationships between all the parameters $(\mathrm{pH}$ Temperature, Salinity, Colour, Conductivity, Turbidity, Odour, TSS, DO, BOD, COD, TDS and THC) measured at different stations. From the plot, the highest bar represented the DPR specification for the TDS and other TDS bars had heights that were almost insignificant compared to this standard specification bar. This showed strict compliance of the refinery plant to the DPR regulation. Another visible indication rom the plot is the THC represented by the blue bars. The DPR THC limit was almost insignificant compared to the different stations. This showed that the specified THC was not being adhered to and measures to ensure strict adherence must be put in place. The next observable sets of bars were those representing the Salinity, Colour and Conductivity. For each of these bars, the DPR standard limit bar cannot be noticed since the standard specification for such parameters were not provided. The temperature bars are almost of equal height and only a closer look revealed that the DPR bar was slightly higher than the rest, an indication that the measured temperatures was very close to the specified standard and therefore further regulation of the temperature may not be necessary.

\section{Conclusion}

This study determined the extent to which partially treated refinery effluent polluted the Okrika River. The results indicated that the value of THC (444.2656.0) and turbidity (17-23) were high. Dissolved Oxygen (DO) had value less than DPR and WHO limit of 5 and 10 respectively. Low DO value was an indication of insufficient oxygen in the river which resulted in suffocation of fishes in the river. The study concluded that the discharge of partially treated effluent from the refinery into the river had significant polluting effects on the Okrika River. Therefore, the natural habitat of the river was threatened and the source of water for livelihood of hundreds of peasants along the river was affected. The study recommended that efficient treatment of effluent before discharge; regulatory agencies should impose polluter pay fine and compensation for host communities and adequate monitoring and surveillance to ensure the protection of the river from further degradation.

\section{References}

1. Odumosu AOT (1992) Management of liquid industrial wastes, paper presented at a seminar on industrial waste management. Inter match pp: 6

2. Adekunle A, Kehinde IT (2008) Impact of industrial effluents on quality of segment of Asa River within an industrial estate in Ilorin, Nigeria.

3. FEPA (1991) Guideline and standard for environmental pollution control in Nigeria. Federal environmental protection agency. FG Press 238.

4. Kanu, ljeoma, Achi OK (2011) Industrial effluents and their impact on water Quality of Receiving Rivers in Nigeria.

5. Suflita JM, Robinson J M, Tiedje JM (1983) Kinetics of microbial dehalogenation of haloaromatic substrates in methanogenic environment. Applied and Environmental Microbiology 45: 1466-1473.

6. Thomas JM, Ward CH, Raymond RL, Wilson JT, Lohehr RC (1992) Bioremediation. In Encyclopedia of Microbiology I (Eds) Academic Press London 369-377.

7. World Bank (1998) Petroleum refinery, pollution prevention and abatement handbook. World Bank pp: 37-80.

8. Sangodoyin (1991) Water source pollution and disease diagnosis in a Nigerian Rural community International Journal of Environmental Education and Information 10: 87-100.

9. Sulphey MM (2013) Introduction to Environmental Management. Published by Asoke K Ghosh, PHI learning Private limited, Rimjhim, Delhi. ( ${ }^{\text {nd }}$ Eds) pp: 96.

10. Jaji MO, Bamgbose O, Arowolo TA, Odukoya OO (2007) Water quality assessment of Ogun river, South west Nigeria. Environ Monit Assess 133: 473-482.

11. Vesiland PA, Peirce JJ, Weiner RF (1990) Environmental Pollution and control. ( $3^{\text {rd }}$ Eds) Butter Worth Heinmann Bosten pp: 406.

12. Fakayode SO (2005) Impact assessment of Industrial effluent on quality of the receiving Alaro River in Ibadan, Nigeria Ajeam-Ragee pp: 1-13

13. Fair P(1971)A Hypothesisconcerning siliciaand fresh water planktonicdiatoms. Limnol. Oceanogr 16: 10-18.

14. Chhatwal, Ratni Johar (2012) Environmental science, a system approach. A publication of UDH and distributors $(P)$ Ltd, New Delhi. ( $\left.2^{\text {nd }} E d s\right)$ pp: 96.

15. World Health Organization (2004) World health organization guidelines for drinking water quality ( $3^{\text {rd }}$ Eds). Geneva, Switerland.

16. Iworh CE (2015) Effect of partially treated effluent on the surrounding surface water Quality (A case study of Okrika River). A study in partial fulfillment for the award of Bachelor degree of Engineering (Environmental Engineering), University of Port Harcourt River State. pp: 7-35.

17. Mbanene FCN, Okoli CG, Ekewegi C (2013) The impact of refinery effluent in the physiochemical regime of Ekerekana creek in Okrika mainland, Rivers State, Nigeria 1: 255-271. 
Citation: John NU, Chimka El. Effect of Discharge of Partially Treated Refinery Effluent on the Okrika River. J Environ Stud. 2017;3(2): 6.

\section{ISSN: $2471-4879$}

18. Ogedengbe K, Akinbile CO (2004) "Impact of Industrial Pollutants on Quality of Ground and Surface Waters at Oluyole Industrial Estate, Ibadan, Nigeria". Nigeria. Academic Journals 4: 139-144.

19. Osibanjo O, Adegbenro PD, Adewole MC (2011) The Impact of Industries on surface water quality of River Ona and River Alaro in Ibadan, Nigeria. Academic Journals 10: 696.

20. Uzoekwe SA, Oghosanine FA (2011) The effect of refinery and Petrochemical effluent on water Quality of Ubeji creek Warri, Southern Nigeria. J Environ Manage 4. 